Immigration and Race 



\section{Immigration and Race}

New Challenges for

American Democracy

Edited by Gerald D. Jaynes

Yale University Press

New Haven and London 
Copyright (C) 2000 by Yale University. All rights reserved.

This book may not be reproduced, in whole or in part, including illustrations, in any form (beyond that copying permitted by Sections 107 and I08 of the U.S. Copyright Law and except by reviewers for the public press), without written permission from the publishers.

Printed in the United States of America.

\section{Library of Congress Cataloging-in-Publication Data}

Immigration and race : new challenges for American democracy / edited by Gerald D. Jaynes.

p. $\quad \mathrm{cm}$.

Includes bibliographical references and index.

ISBN 0-300-07380-I (cloth : alk. paper)—ISBN o-300-08005-o (pbk. : alk. paper)

I. United States-Race relations-Congresses. 2. United States-Race relations-Political aspects-Congresses. 3. United States-Emigration and immigration-Government policy_Congresses. 4. United States-Emigration and immigration-Social aspects-Congresses. 5. Afro-Americans-Social conditions-1975-Congresses. 6. Immigrants—United States—Social conditions-Congresses. 7. Afro-Americans-Politics and government-Congresses. 8. Immigrants—United States—Political activity—Congresses. I. Jaynes, Gerald David.

EI84.Ar I4365 2000 $305.8^{\prime} 00973-\mathrm{dc21}$

A catalogue record for this book is available from the British Library.

The paper in this book meets the guidelines for permanence and durability of the Committee on Production Guidelines for Book Longevity of the Council on Library Resources.

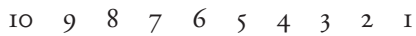

